\title{
CORRIGENDUM
}

\section{IL-12 gene-modified bone marrow cell therapy suppresses the development of experimental metastatic prostate cancer}

\section{H Wang, G Yang, TL Timme, T Fujita, K Naruishi, A Frolov, MK Brenner, D Kadmon and TC Thompson}

Cancer Gene Therapy (2007) 14, 873-874; doi:10.1038/sj.cgt.7701084

Correction to: Cancer Gene Therapy (2007) 14, 819-827; e-pub ahead of print 13 July 2007;

doi:10.1038/sj.cgt.7701069

In the above article, the authors have found an error in Figure 1

The correct $P$-values that are stated in the Results section are $P=0.0036$ (comparing DFG-mIL-12 with
HBSS) and $P=0.0197$ (comparing DFG-mIL-12 with DFG-eGFP).

The correct figure is shown below.

The authors would like to apologize for this mistake.
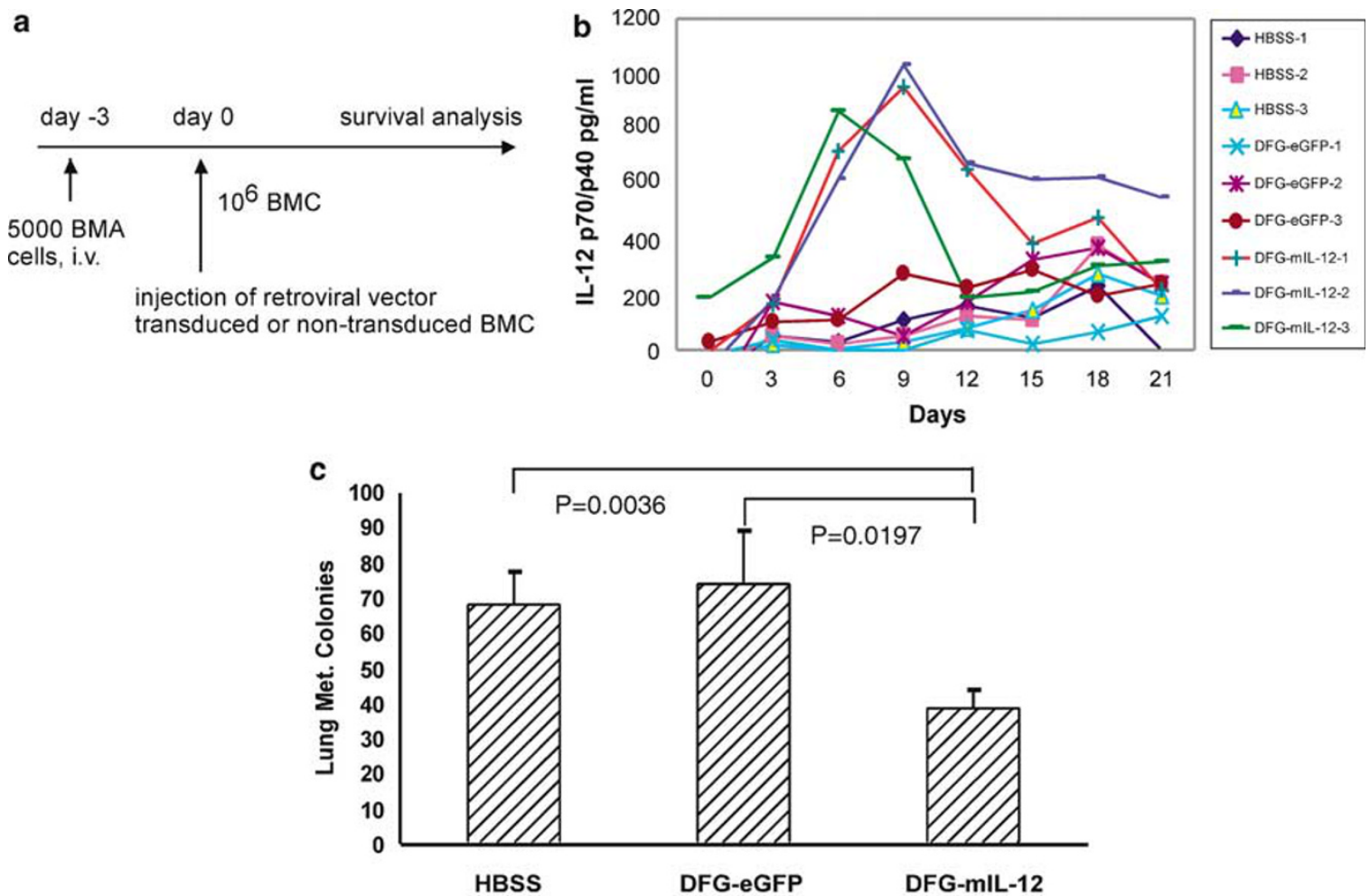

Figure 1 Anti-metastatic effect of DFG-mIL-12-transduced BMC. Retroviral vector-transduced 129/Sv Rosa BMC $\left(10^{6}\right)$ were injected via the tail vein into recipient $129 / \mathrm{Sv}$ male mice without prior bone marrow ablation 3 days following tumor cell injection. The experimental scheme is shown in (a). Serum IL-12 level was monitored by ELISA (p70/p40) at 3-day intervals following retroviral vector-transduced BMC treatment $(\mathrm{MOI}=2)$ (b). At day 21 after treatment, lungs were removed and fixed in Bouin's solution. Formation of lung metastatic colonies was quantified in (c). Femurs were fixed and stained with H\&E. Formation of bone metastasis at low and high magnification in mice treated with DFG-eGFPtransduced BMC (d and $\mathbf{e}$, respectively), and in mice treated with DFG-mIL-12-transduced BMC ( $\mathbf{f}$ and $\mathbf{g}$, respectively). Data are representative of three mice per group per experiment of two independently performed experiments. H\&E, hematoxylin and eosin stain. 

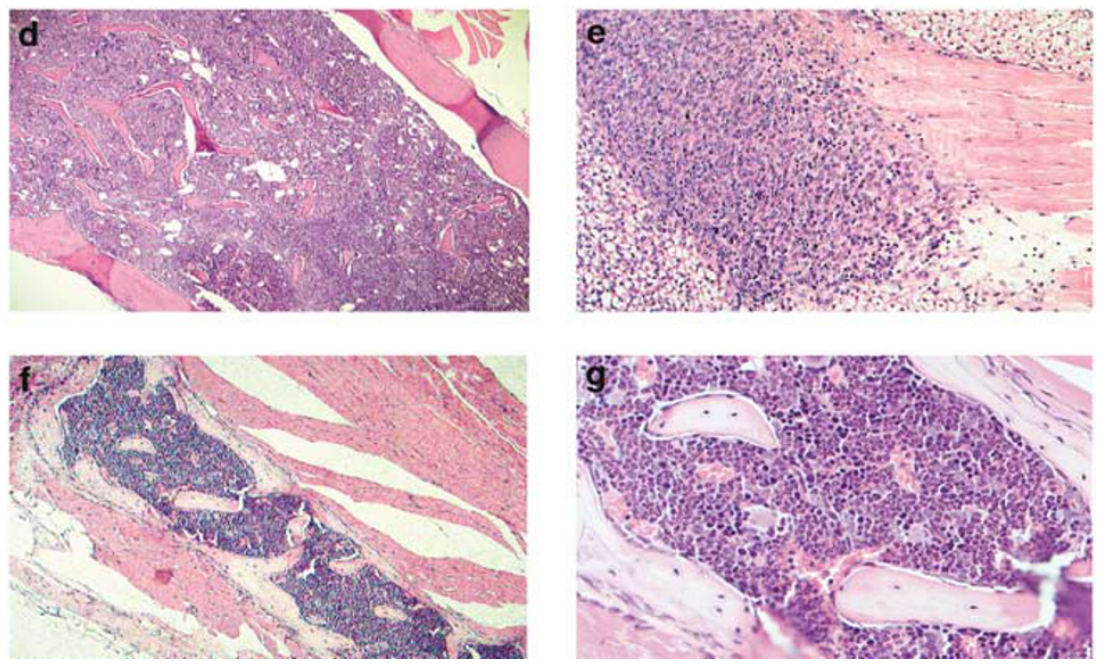

Figure 1 Continued. 